\title{
The technology and application of cable force monitoring for spatial cable structure
}

\author{
Guo Nan ${ }^{a}$, Wang Xin-gang ${ }^{a}(\mathbb{D})$,Lan Chun-guang ${ }^{b *}$ \\ a College of Civil Engineering, Northeast Forestry University, Harbin 150040, China. E-mail: snowguonan@163.com, 515689718@qq.com \\ ${ }^{b}$ Beijing construction engineering research institute co., Ltd., Beijing 100039, China. E-mail: Icg98011210@163.com
}

* Corresponding author

https://doi.org/10.1590/1679-78256807

\begin{abstract}
According to the need of cable force monitoring of space cable structure, a new fiber Bragg grating monitoring method is proposed by analyzing the mechanism, advantages and disadvantages and application scope of existing cable force monitoring methods. The results of practical engineering show that: the mechanism of this method is clear and easy to implement; the advantages of clamp cable, tension meter, and Jack monitoring method are fully used to avoid their disadvantages; in the mutual check stage of Jack and clamp cable tension meter, the monitoring data error of the two testing methods is less than $5 \%$, which indicates that the clamp strain gauge is accurate and effective; this method has little influence on construction, and can make full use of the engineering project The clamp cable tension meter is arranged in the process of cable tension in stages, which can realize the implementation without affecting the original construction process. It provides an experience reference for similar cable tension process and cable force control in service stage in the future.
\end{abstract}

Keywords

Spatial cable structure; Tensioning process; Cable force monitoring; Clamp cable tension meter; Fiber grating

\section{Graphical Abstract}
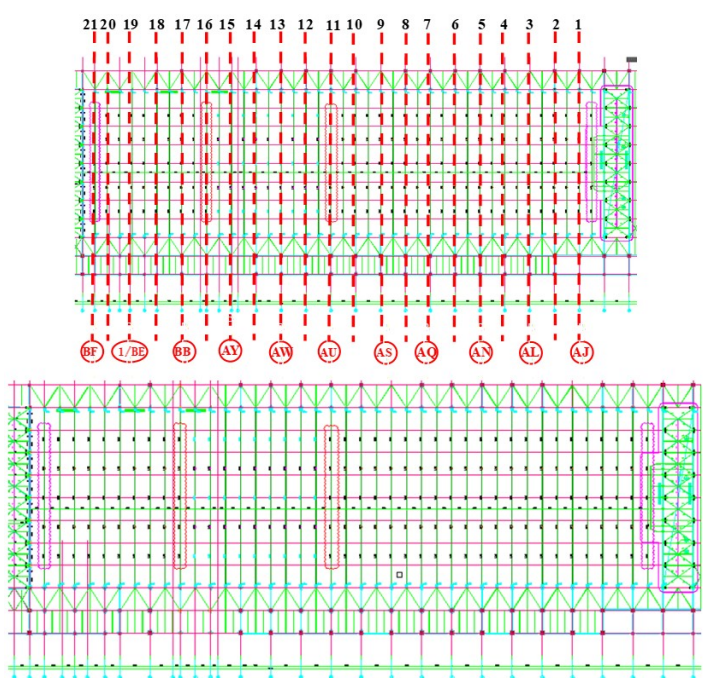


\section{INTRODUCTION}

The development of modern suspension structures in China began in the late 1950s and 1960s. Beijing Workers' Stadium was one of the representative works at that time. Although there are some outstanding projects, it must be acknowledged that the development of large-span space structure in China is far from that of the international development level at that time. However, in the past 20-30 years, almost all kinds of suspension structures have been explored in our engineering practice, and space cable structures have made great progress. With the establishment of a large gymnasium, convention center, and other space cable structures in the city, cable force monitoring of space cable structures has become an increasingly concerned topic (Zhao Wenju et al. 2020; Xin Cui, et al. 2013; Y. Zhao and M. L. Wang 2008).

Cable is the main bearing component of the space cable structure. Forming of the structure system, load, internal force distribution, and overall safety of the structure are all concentrated on the cable force. Due to the lack of effective cable force monitoring means for space cable structures, once stress concentration occurs, individual prestressed cables will break and fail, which will affect the normal operation of the structure. It will lead to accidents and irreparable losses (Smedt Elien, et al. 2021; M. Rezaiee-Pajand and M. M. Khatami, 2021; Lee Sung Hwa, et al. 2009; Song Jong Keol, et al. 2008; Deqing Guan et al. 2015). At the present stage, due to the relatively closed structure characteristics and construction technology of cable structure, although many scholars have made many beneficial explorations in cable structure monitoring and obtained effective methods, the conditions and characteristics of each method have not been specifically analyzed. And for cable structures which are greatly affected by wind loads, the time-varying requirement of monitoring is very high, so it is still a difficult problem to select an appropriate monitoring method and build a real-time monitoring system (Guo-Xi Fan, et al. 2020; Lejiang Guo, et al. 2011; Xushe Zhang et al. 2005; R. Maaskant et al. 1997; Ujiwara, T. et al. 1993).

To solve the above problems, based on the analysis of the mechanism and characteristics of the existing cable force monitoring methods (Sung Tae Kim, et al. 2014; José R. Alves Cunha, et al. 2013; Hong-yue Liu, et al. 2012; Wei Wu, et al. 2009), this paper proposes a joint monitoring method of clamp cable, force meter, and Jack Based on the fiber Bragg grating sensing principle. In this method, the jack is used to test the cable force in the early stage of construction, the fiber Bragg grating clamp cable tension meter and Jack are used to check the monitoring in the middle stage of construction, and the fiber Bragg grating clamp cable tension meter is used to monitor the cable force in the construction stage and the operation stage; The effectiveness and superiority of this method are verified by practical engineering.

\section{Analysis of common cable force monitoring methods}

Table 1 shows the principle, advantages, and disadvantages of the commonly used cable force monitoring methods at this stage, as well as the detailed analysis of the applicable stages. Through the analysis of the table, it can be seen that the monitoring methods of cable force at present are various, and the applicable conditions are relatively harsh. This table can provide guidance and reference for the selection of cable force monitoring methods in actual projects.

\section{The joint monitoring method of clamp cable force meter and Jack}

\subsection{Principle of joint monitoring}

According to the analysis in Table 1, under the premise of not affecting the construction period; On the basis of no change or less intervention in the original construction process, the combined monitoring method of optical fiber clamp cable tension meter and Jack can be used to realize the accurate monitoring of the whole life cycle of the cable. The monitoring method mainly includes three stages: 1 . In the early stage of cable construction (from the beginning of construction to $1 / \mathrm{N}$ tension control force), Jack is used to monitor the cable force; 2 . In the later stage of cable construction (from 1 / $\mathrm{N}$ tension control force to tension control force), Jack and clamp cable force meter are used to collect cable force data synchronously and check each other; 3 . In the service stage of the cable (after the jack is removed), the clamp cable tension meter is used to monitor the cable force. Through the comprehensive application of the two methods, the disadvantages of the two monitoring methods can be effectively avoided, and the advantages of the two methods can be brought into full play, to realize the low-cost and high-precision cable force life-cycle monitoring of space cable structure. 
Table 1 Analysis table of cable force measurement method

\begin{tabular}{|c|c|c|c|c|}
\hline $\begin{array}{l}\text { Cable force measurement } \\
\text { method }\end{array}$ & Measuring principle & Advantages & Shortcomings & Application stage \\
\hline \multirow[t]{2}{*}{ Magneto-Elastic Method } & \multirow[t]{2}{*}{$\begin{array}{l}\text { The magnetic flux is related to } \\
\text { the stress and temperature, } \\
\text { and the cable force is } \\
\text { calculated by measuring the } \\
\text { magnetic flux. }\end{array}$} & $\begin{array}{l}\text { 1.The cables with complex } \\
\text { boundary conditions can be } \\
\text { solved theoretically. }\end{array}$ & $\begin{array}{l}\text { 1. Each cable has a unique } \\
\text { relationship curve between } \\
\text { the output voltage of the } \\
\text { magnetic flux sensor and the } \\
\text { cable force, so it must be } \\
\text { calibrated before leaving the } \\
\text { factory, which is time- } \\
\text { consuming and laborious. }\end{array}$ & \multirow[t]{2}{*}{$\begin{array}{l}\text { Construction period and } \\
\text { service period }\end{array}$} \\
\hline & & $\begin{array}{l}\text { 2. The mechanical and } \\
\text { physical properties of the } \\
\text { cable body will not be } \\
\text { damaged. }\end{array}$ & $\begin{array}{l}\text { 2. Long construction period } \\
\text { required }\end{array}$ & \\
\hline \multirow[t]{3}{*}{$\begin{array}{l}\text { Resistance strain gauge } \\
\text { measurement method }\end{array}$} & \multirow{3}{*}{$\begin{array}{l}\text { There is a certain relationship } \\
\text { between the resistance and } \\
\text { strain of the resistance strain } \\
\text { gauge. The cable body strain } \\
\text { can be obtained according to } \\
\text { the resistance change rate } \\
\text { when the cable body is } \\
\text { deformed, and the cable force } \\
\text { can be calculated. }\end{array}$} & $\begin{array}{l}\text { 1. The operation is simple and } \\
\text { fast. }\end{array}$ & $\begin{array}{l}\text { 1. The resistance method will } \\
\text { cause irreversible damage to } \\
\text { the cable surface and reduce } \\
\text { the durability of the cable. }\end{array}$ & \multirow[t]{3}{*}{ construction period } \\
\hline & & 2. Low measurement cost. & $\begin{array}{l}\text { 2. The measurement accuracy } \\
\text { is average. }\end{array}$ & \\
\hline & & $\begin{array}{l}\text { 3. The required construction } \\
\text { period is short }\end{array}$ & $\begin{array}{l}\text { 3. Unable to measure for a } \\
\text { long time. }\end{array}$ & \\
\hline \multirow[t]{2}{*}{$\begin{array}{l}\text { Frequency measurement } \\
\text { method }\end{array}$} & \multirow{2}{*}{$\begin{array}{l}\text { Based on the principle of } \\
\text { string vibration, the } \\
\text { relationship between } \\
\text { vibration frequency and cable } \\
\text { force is determined, and the } \\
\text { measured frequency is } \\
\text { converted into cable force. }\end{array}$} & $\begin{array}{l}\text { 1. Engineering is widely used } \\
\text { and the method is mature. }\end{array}$ & $\begin{array}{l}\text { 1. It is difficult to derive the } \\
\text { cable force-frequency formula } \\
\text { under complex boundary } \\
\text { conditions. }\end{array}$ & \multirow[t]{2}{*}{$\begin{array}{l}\text { Construction period and } \\
\text { service period }\end{array}$} \\
\hline & & $\begin{array}{l}\text { 2. The accuracy meets the } \\
\text { requirements. }\end{array}$ & $\begin{array}{l}\text { 2. It is difficult to pick up the } \\
\text { frequency of the cable } \\
\text { section. }\end{array}$ & \\
\hline \multirow[t]{3}{*}{$\begin{array}{l}\text { Clamp cable tension meter } \\
\text { measurement method }\end{array}$} & \multirow{3}{*}{$\begin{array}{l}\text { The strain is transmitted to } \\
\text { the optical fiber sensor } \\
\text { through the codeformation of } \\
\text { the clamp and cable body, } \\
\text { and then the stress is } \\
\text { obtained by Hooke's law, and } \\
\text { the cable force is calculated. }\end{array}$} & $\begin{array}{l}\text { 1. The construction is simple } \\
\text { and convenient. }\end{array}$ & $\begin{array}{l}\text { 1. When the cable force of the } \\
\text { cable body is small, the } \\
\text { accuracy is low. }\end{array}$ & \multirow[t]{3}{*}{$\begin{array}{l}\text { Construction period (later } \\
\text { period) and service period }\end{array}$} \\
\hline & & $\begin{array}{l}\text { 3. It does not affect the } \\
\text { construction period and is } \\
\text { easy to set up. }\end{array}$ & $\begin{array}{l}\text { 3. The measurement accuracy } \\
\text { is greatly affected by the } \\
\text { degree of coordinated } \\
\text { deformation of the clamp and } \\
\text { cable body. }\end{array}$ & \\
\hline & & $\begin{array}{l}\text { 4. Real-time monitoring can } \\
\text { be realized with low cost. }\end{array}$ & & \\
\hline \multirow[t]{2}{*}{ Jack measuring method } & \multirow{2}{*}{$\begin{array}{l}\text { The tension of cable body is } \\
\text { provided by jack. Reliable } \\
\text { cable force can be obtained } \\
\text { by installing an active oil } \\
\text { pump and pressure gauges on } \\
\text { the cable body. }\end{array}$} & $\begin{array}{l}\text { 1. Simple and reliable cable } \\
\text { force collection is realized in } \\
\text { the construction process. }\end{array}$ & $\begin{array}{l}\text { 1. During construction, } \\
\text { relevant shutdown nodes } \\
\text { need to be found to give the } \\
\text { data recording time. }\end{array}$ & \multirow[t]{2}{*}{ construction period } \\
\hline & & $\begin{array}{l}\text { 2. No additional equipment or } \\
\text { facilities will be added. }\end{array}$ & $\begin{array}{l}\text { 2. Cable forces cannot be } \\
\text { tracked further after forming. }\end{array}$ & \\
\hline \multirow[t]{3}{*}{$\begin{array}{l}\text { Intelligent cable } \\
\text { measurement }\end{array}$} & \multirow{3}{*}{$\begin{array}{l}\text { During cable making, } \\
\text { packaged optical fiber sensors } \\
\text { are embedded in the cable } \\
\text { body to obtain cable force } \\
\text { through optical fiber sensing. }\end{array}$} & $\begin{array}{l}\text { 1. The strain at any position of } \\
\text { the cable body can be } \\
\text { obtained to realize the } \\
\text { distributed measurement. }\end{array}$ & 1. Higher costs. & \multirow[t]{3}{*}{$\begin{array}{c}\text { Construction period and } \\
\text { service period }\end{array}$} \\
\hline & & $\begin{array}{l}\text { 2. High measurement } \\
\text { accuracy. }\end{array}$ & $\begin{array}{l}\text { 2. Long construction period is } \\
\text { required, and the composite } \\
\text { sensing ribs need to be } \\
\text { embedded in advance when } \\
\text { the cable is fabricated. }\end{array}$ & \\
\hline & & ig. & & \\
\hline
\end{tabular}

\subsection{Monitoring cable force with Jack}

The jack cable force monitoring is realized by the calibrated pressure gauge on the oil pump during cable construction. Considering the jack cable force monitoring method has been verified in the cable construction process for 
many years, and formed the relevant specifications, which will not be repeated here. The photo of the device is shown in Figure 1.

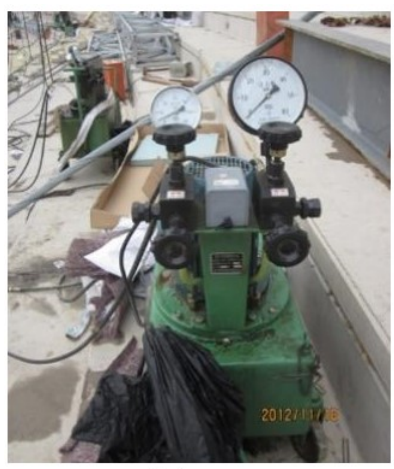

(a)

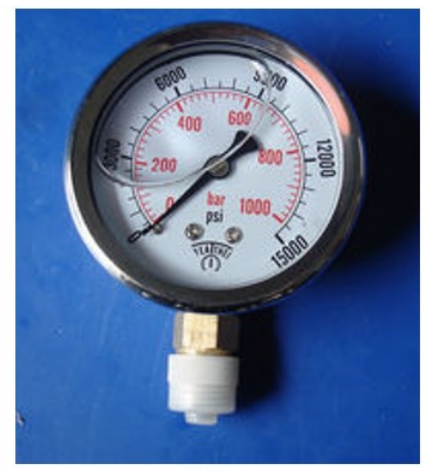

(b)

FIGURE 1 Cable tension testing instrument:(a) Oil pump + pressure gauge;(b)pressure gauge.

\subsection{Clamp cable tension meter based on optical fiber sensing technology}

\subsubsection{Basic principle of clamp cable tension meter}

The clamp cable tension meter transmits the strain to the optical fiber sensor through the cooperative deformation of the clamp and the cable body, and then obtains the stress through Hooke's law, and then calculates the cable force. The core part is the selection of sensor elements and the design of the clamp. Considering that the spatial cable structure is generally a large-span roof structure, which is greatly affected by the wind load, the frequency of wind load is generally $1-5 \mathrm{~Hz}$, and the general monitoring frequency is required to be 5-10 times of the frequency of the monitored quantity, that is, the frequency of cable force monitoring should be $5-50 \mathrm{~Hz}$. In view of the above analysis, this paper selects the clamp cable tension meter based on Fiber Bragg grating sensor. Fiber Bragg grating (FBG) is one of the most promising fiber devices in structural health monitoring technology. It is a passive device with periodic refractive index changes in the fiber core. Among them, fiber Bragg grating is the most simple and common one, whose refractive index, modulation depth, and grating period are constant. Figure 2 is the working principle diagram of the FBG sensing system. The light and dark change of the fiber core in the figure represents the position of the fiber grating. When a broadband light source is used with be incident from one end of the fiber Bragg grating, the forward and backward light waves in the fiber core are coupled due to the periodic change of the refractive index. When the light frequency of the wavelength satisfying Bragg condition is coupled to the backward transmission wave, the peak value is formed in the reflection spectrum and the depression is formed in the transmission spectrum. Fig. 2 is the working principle diagram of fiber Bragg grating sensing system.

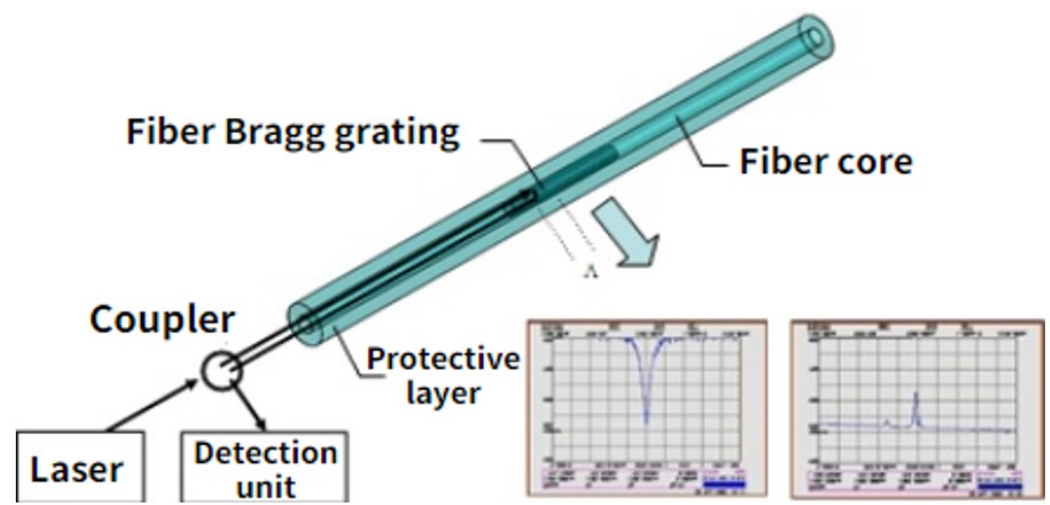

FIGURE 2 Working principle diagram of fiber Bragg grating sensing system

The elastic modulus and effective metal cross-sectional area of the cable are known when the cable leaves the factory. Based on the linear relationship between the shift of the center wavelength of the fiber Bragg grating and the axial strain of the object to be measured, a clamp cable force meter measurement method is proposed according to the cable structure. In the elastic range of the cable, the strain of the cable is measured by the cooperative deformation of the clamp strain gauge and the cable, and then the cable force is calculated by Hooke's law. 
Specific cable tension measurement process is as follows. When the cable is tensioned to $1 / \mathrm{N}$ tension control force, a clamp cable tension meter (with temperature compensation) is installed on the cable body as the zero state of the clamp strain gauge and the initial wavelength $\left(\lambda_{0}\right)$ of the FBG strain sensor and the temperature compensated grating $\left(\lambda_{0}^{T}\right)$ at this moment are recorded. When the cable is tensioned to a preset tension control force, the wavelength of the strain sensor $\left(\lambda_{s}\right)$ and the temperature compensated grating $\left(\lambda_{\mathrm{s}}^{T}\right)$ are acquired.

Cable forces during the tension stage are calculated as follows:

Wavelength variation of FBG strain sensor during $30 \%-100 \%$ tension control force process:

$\Delta \lambda_{\mathrm{s}}=\lambda_{\mathrm{s}}-\lambda_{0}$

Wavelength variation of temperature compensated grating at this stage:

$\Delta \lambda_{\mathrm{s}}^{T}=\lambda_{\mathrm{s}}^{T}-\lambda_{0}^{T}$

The wavelength change of the FBG strain sensor caused by strain only at this stage:

$\Delta \lambda_{\mathrm{s}}^{\varepsilon}=\Delta \lambda_{\mathrm{s}}-\Delta \lambda_{\mathrm{s}}^{T}$

According to the sensing principle of $F B G$, the change of the central wavelength value of $F B G$ is proportional to the strain with a coefficient of $k=1 /(1-P)$, where $P$ is the effective photo-elastic coefficient of $F B G$, then the strain of the cable at this stage is:

$\varepsilon_{s}=k \Delta \lambda_{s}^{\varepsilon}$

According to Hooke's law, the cable force increment at this stage is( $E$ and $A$ represent the elastic modulus and the effective metal section area of the cable, respectively.):

$F_{S}=\varepsilon_{S} \cdot E \cdot A$

The cable force value converted linearly for the whole construction process is:

$F_{\text {sall }}=F_{S} /(1-1 / N)$

The calculation of cable force in the service stage is as follows: Similar to the calculation of cable tension in the cable tension stage, $100 \%$ tension control force is taken as the zero state of cable tension analysis in the cable service stage. When the initial wavelength of the fiber Bragg grating strain sensor is " $\lambda_{s}$ " and the wavelength of the temperature compensated grating is " $\lambda_{s}^{T "}$, the wavelength change of the cable force sensor at the " $i$ " moment relative to the tension control force of $100 \%$ is as follows:

$\Delta \lambda_{\mathrm{i}}^{\varepsilon}=\Delta \lambda_{\mathrm{i}}-\Delta \lambda_{\mathrm{i}}^{T}=\left(\lambda_{\mathrm{i}}-\lambda_{\mathrm{s}}\right)-\left(\lambda_{\mathrm{i}}^{T}-\lambda_{\mathrm{s}}^{T}\right)$

Similarly, the variation of cable force in this stage is as follows:

$F_{i-\mathrm{s}}=\Delta \lambda_{\mathrm{i}}^{\varepsilon} \cdot E \cdot A$

Considering that the calculation at this stage is to calculate the moment when the tension control force is $100 \%$ at zero state, then the absolute value of the cable force at time " $\mathrm{i}$ " is:

$F_{i}=F_{\text {sall }}+F_{i-\mathrm{s}}$ 


\subsubsection{Design and implementation of clamp cable tension meter}

It can be seen from Table 1 that the measurement of the clamp cable tension meter must ensure the cooperative deformation of the clamp and the cable body, and the measured data will be reliable. Due to the extrusion between the steel wires in the cable body during the tensioning process, the diameter of the cable body will shrink, and the relative slip between the clamp and the cable body may occur. Therefore, the key to the clamp measurement method is to ensure the firm connection between the cable body and the clamp. The fastening force between the clamp and the cable body is the key factor to reflect the connection degree between the clamp and the cable body, therefore, two groups of highstrength bolts are used to ensure the foundation fastening force in the clamp design, and a spring gasket is added under the cushion block. The spring gasket is added to make the spring in the state of energy storage in the use stage. When the cable body diameter shrinks, the spring gasket releases energy to compensate the clamp tightening force, so as to reduce the relative slip. Figure 3 is the design drawing of the clamp cable tension meter and the physical drawing before and after installation.

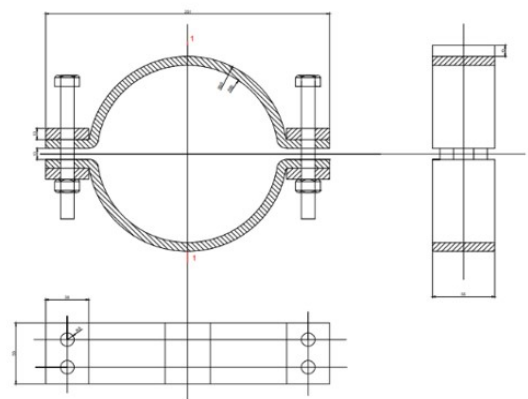

(a)

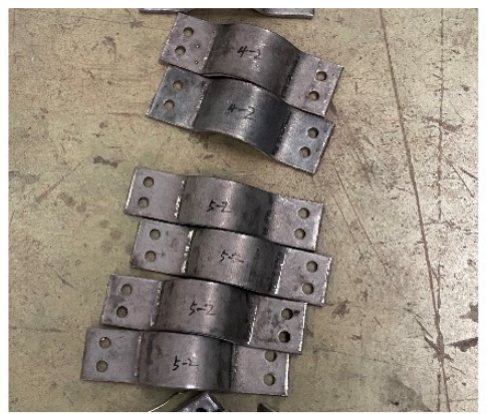

(b)

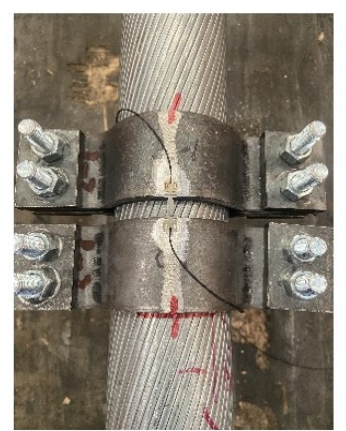

(c)

FIGURE 3:Design drawing and physical drawing of clamp: (a) Three views of clamp design drawing;(b) Machined clamp diagram;(c) Clamp and wire rope after installation.

\section{Applications of demonstration project}

\subsection{Project overview}

The roof structure of National Conference Center Phase II project mainly includes roof garden, roof lattice shell, banquet hall roof truss, and hall roof truss structure. The structural layout is shown in Figure 4 . There are 85 main beams with a span of $72 \mathrm{~m}$ and 4928 connecting beams in the roof lattice shell of the roof garden, totaling about 10000 tons. There are 6 roof trusses of the banquet hall with a span of $72 \mathrm{~m}$. Each truss weighs about 95 tons, with a total of about 700 tons.

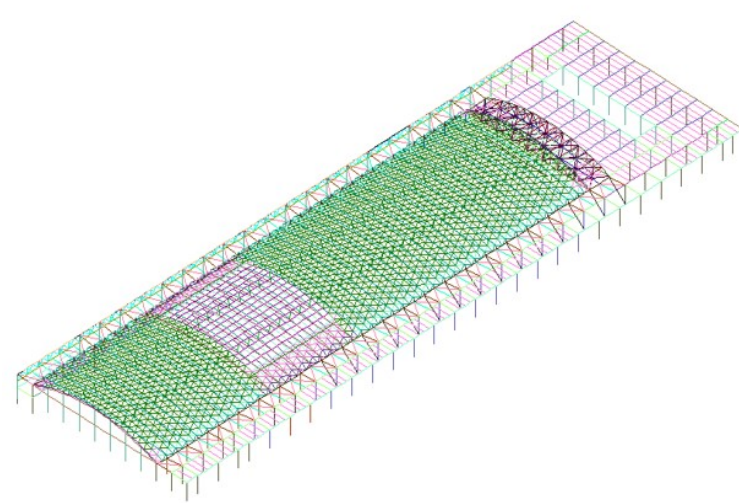

(a)

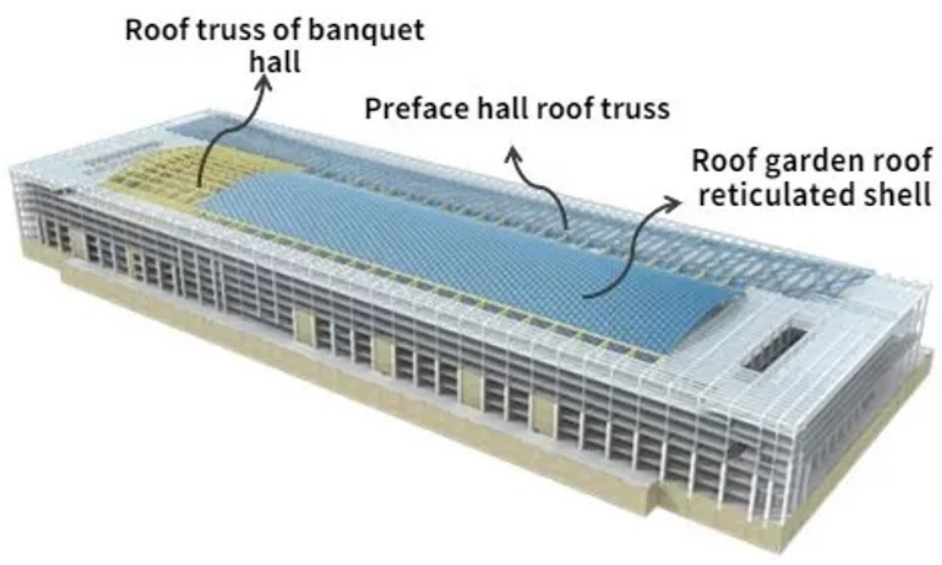

(b)

FIGURE 4:3D view and roof garden shell axis side view of National Conference Center Phase II project.:(a) Axis Diagram of Roof Garden Lattice Shell;(b) Three-dimensional view of the roof structure. 
The construction steps of the roof steel structure are as follows: the steel structure truss is installed on three jig frames, respectively, and after the installation, it is tensioned to $50 \%$ of the tension control force. Slip after inspection, and then install the next steel structure on the original jig, and then slip. After the cables slide in place and the jig is removed and installed, the cables are tensioned for the second time until they meet the design requirements.

\subsection{Design of monitoring system}

\subsubsection{Layout scheme}

In the service stage, the main active cable force is monitored to control the cable net construction. Therefore, the monitoring cable force of this project adopts the clamp type strain gauge, which is arranged every other cable, with a total of 21 cables.

\subsubsection{Selection of monitoring instruments}

The sensor is Os3155 strain sensor produced by Singapore Xinte company. It is a fiber Bragg grating strain sensor with temperature compensation, which is suitable for strain measurement of outdoor steel structure surface. The substrate of Os3155 strain sensor is made of stainless steel, which can protect the optical fiber during the installation process. The grating is fixed on the stainless steel substrate and is in the pre-tension state. Os3155 strain sensor uses non-adhesive packaging technology to ensure the long-term reliability of the sensor. The physical drawing of optical fiber sensor and optical fiber demodulator selected in this test is shown in Figure 5.

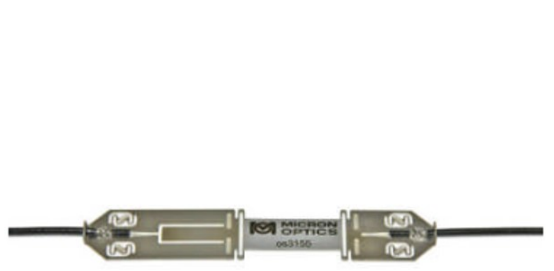

(a)

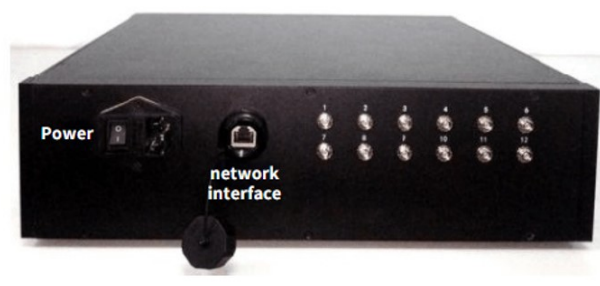

(b)

FIGURE 5:Instrument Selection of Project Strain Acquisition System:(a)Os3155Fiber Bragg Grating Strain Sensor;(b)TV125 Fiber grating demodulator.

\subsection{Specific implementation process}

The cable construction of this project is divided into two stages, namely, the stage of $50 \%$ tension control force and the stage of $100 \%$ tension control force. It took about two and a half months. Due to the limitation of monitoring conditions, automatic acquisition can not be realized. During the construction period of the project, the manual acquisition method is mainly used, and the monitoring cable force is all 42 cables, of which 21 cables are selected by the joint monitoring method. The deployment time of clamp cable force is after the completion of the first stage of tension. The photo after actual installation is shown in Figure 6. The layout plan of the clamp cable tension meter is shown in Figure 7, and the layout plan of the roof structure cable is shown in Figure 8.

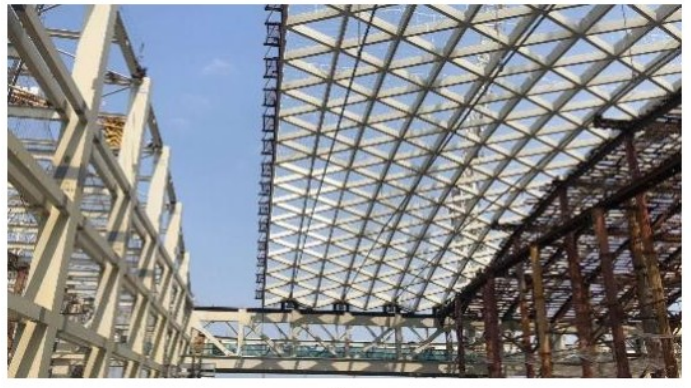

(a)

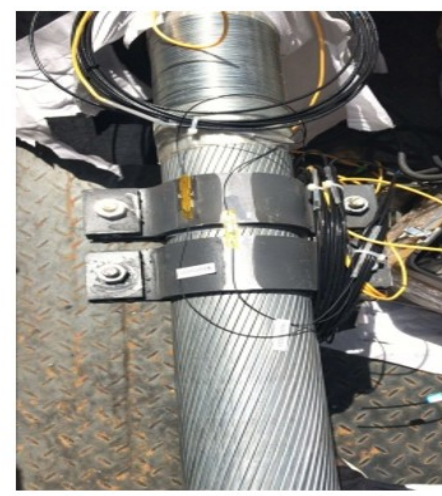

(b)

FIGURE 6: Relevant photos of monitoring system implementation:(a) Overall photo of the roof steel structure;(b) Photo of the cable body with clamp tension meter installed. 


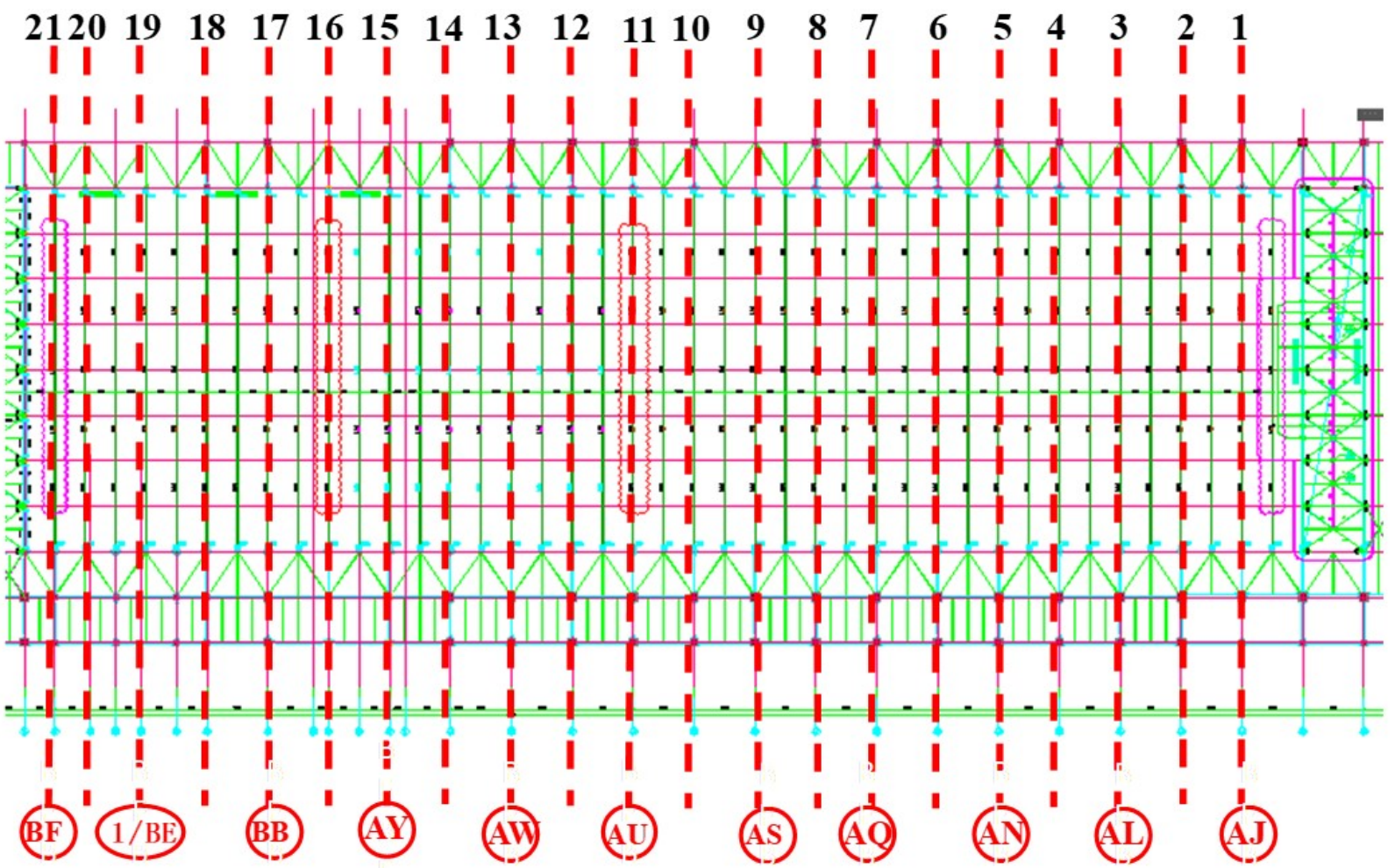

FIGURE 7: Layout plan of clamp cable tension meter. (The red part in the figure represents the clamp cable tension meter.)

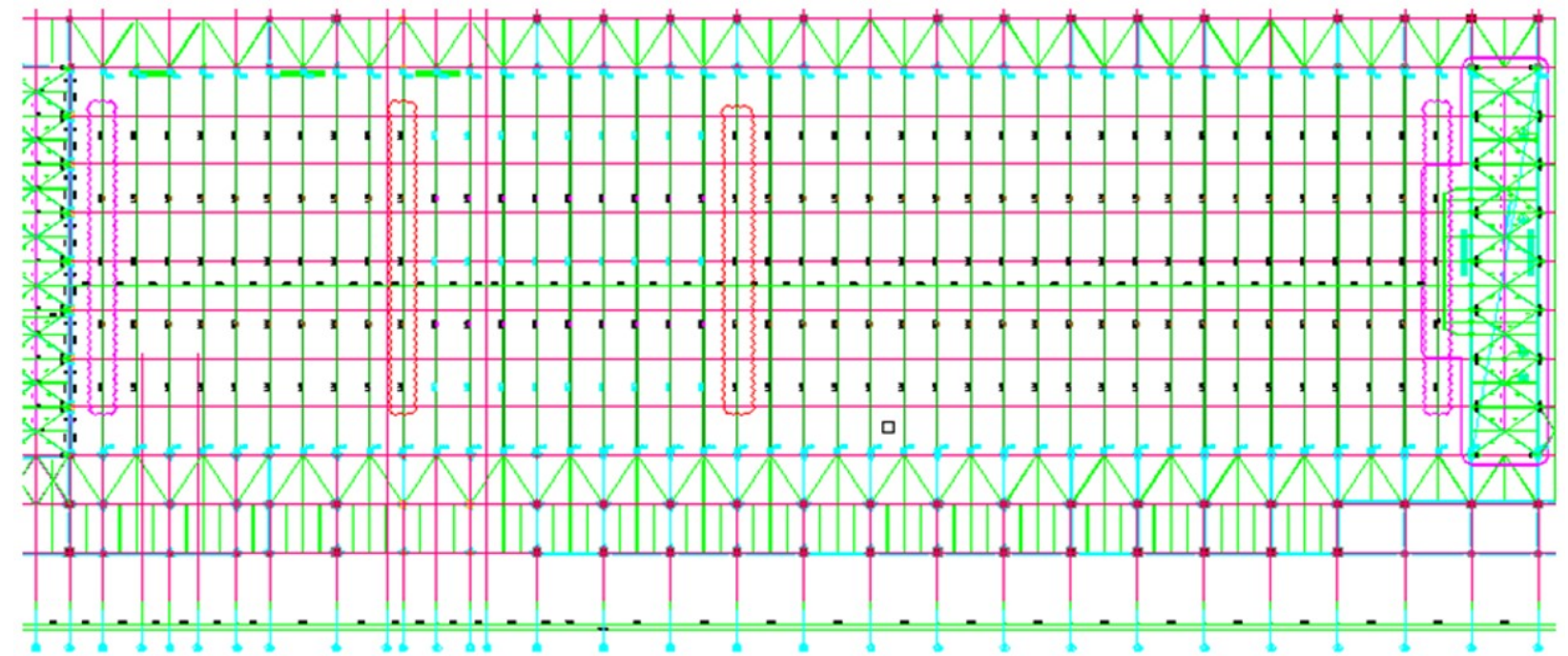

FIGURE 8: Cable layout of roof structure.

\subsection{Analysis of cable tension monitoring data during cable tensioning}

The clamp cable tension meter of this project is laid after the first stage of installation, and the monitoring method is carried out by comparing Jack and clamp tension meter. The data of the jack can be obtained directly from the reading of the pressure gauge during the tension process. Here, only the monitoring data of the clamp tension meter are analyzed. According to the construction process, it can be divided into tension control force stage and post-tension forming stage. Relevant calculation and analysis results are shown in Table 2.

It can be seen from Table 2 that the data of all 21 sensors are collected normally, and compared with the theoretical value, the error in the tension control process is less than $5 \%$ compared with the force value of the jack, the two methods check each other, and the construction accuracy is high. The results show that the joint monitoring method is accurate and feasible and has the least impact on the construction process. 
Table 2:Original data and analysis results during tensioning

\begin{tabular}{|c|c|c|c|c|c|c|c|c|c|c|c|}
\hline \multirow{2}{*}{$\begin{array}{c}\text { Cable } \\
\text { number }\end{array}$} & \multirow{2}{*}{ axis } & \multicolumn{2}{|c|}{$\begin{array}{c}\text { Temperature } \\
\text { grating }(\mathrm{nm})\end{array}$} & \multicolumn{2}{|c|}{ Strain grating(nm) } & \multirow{2}{*}{$\begin{array}{l}\text { stress } \\
\text { (MPa) }\end{array}$} & \multirow{2}{*}{$\begin{array}{c}\text { The } \\
\text { measure of } \\
\text { area }\left(\mathrm{mm}^{2}\right)\end{array}$} & \multirow{2}{*}{$\begin{array}{c}\text { Clamp cable } \\
\text { tension } \\
\text { meter }(\mathbf{k N})\end{array}$} & \multirow{2}{*}{ Jack (kN) } & \multirow{2}{*}{$\begin{array}{l}\text { Cable forces } \\
\text { during } \\
\text { construction } \\
\text { (kN) }\end{array}$} & \multirow{2}{*}{$\begin{array}{c}\text { Percentage } \\
\text { error between } \\
\text { Clamp cable } \\
\text { tension meter } \\
\text { and Jack } \\
\text { measurement }\end{array}$} \\
\hline & & $50 \%$ & $100 \%$ & $50 \%$ & $100 \%$ & & & & & & \\
\hline 3 & $\mathrm{BE}$ & 1530.191 & 1530.182 & 1557.066 & 1558.776 & 286.503 & 6310 & 1808 & 1827 & 3616 & $1.0 \%$ \\
\hline 4 & $1 / B E$ & 1577.637 & 1577.621 & 1553.143 & 1554.792 & 277.491 & 6310 & 1751 & 1779 & 3502 & $1.5 \%$ \\
\hline 6 & $\mathrm{BC}$ & 1538.112 & 1538.114 & 1563.002 & 1564.769 & 294.247 & 6310 & 1857 & 1853 & 3714 & $0.2 \%$ \\
\hline 8 & BB & 1523.531 & 1523.529 & 1544.034 & 1545.819 & 297.838 & 6310 & 1879 & 1881 & 3758 & $0.1 \%$ \\
\hline 10 & BA & 1523.331 & 1523.33 & 1544.072 & 1545.861 & 298.369 & 6310 & 1883 & 1815 & 3766 & $3.6 \%$ \\
\hline 12 & AY & 1538.352 & 1538.352 & 1548.6 & 1550.327 & 287.755 & 8460 & 2434 & 2454 & 4868 & $0.8 \%$ \\
\hline 16 & AW & 1567.391 & 1567.389 & 1521.423 & 1523.075 & 275.679 & 8460 & 2332 & 2344 & 4664 & $0.5 \%$ \\
\hline 17 & AV & 1527.571 & 1527.569 & 1543.901 & 1545.473 & 262.307 & 8460 & 2219 & 2310 & 4438 & $4.1 \%$ \\
\hline 18 & AV & 1523.411 & 1523.412 & 1565.448 & 1567.011 & 260.303 & 8460 & 2202 & 2266 & 4404 & $2.9 \%$ \\
\hline 22 & AT & 1533.724 & 1533.719 & 1528.354 & 1529.410 & 176.832 & 6310 & 1116 & 1146 & 2232 & $2.6 \%$ \\
\hline 24 & AS & 1527.295 & 1527.309 & 1556.549 & 1557.640 & 179.516 & 6310 & 1133 & 1145 & 2266 & $1.0 \%$ \\
\hline 26 & $A R$ & 1530.541 & 1530.553 & 1572.962 & 1574.195 & 203.446 & 6310 & 1284 & 1313 & 2568 & $2.2 \%$ \\
\hline 28 & $A Q$ & 1541.332 & 1541.333 & 1556.334 & 1557.563 & 204.649 & 6310 & 1291 & 1312 & 2582 & $1.6 \%$ \\
\hline 30 & AP & 1575.891 & 1575.941 & 1549.023 & 1550.328 & 209.229 & 6310 & 1320 & 1334 & 2640 & 1.05 \\
\hline 32 & AN & 1530.166 & 1530.171 & 1574.419 & 1575.933 & 251.488 & 6310 & 1587 & 1556 & 3174 & $2,0 \%$ \\
\hline 34 & AM & 1530.208 & 1530.223 & 1551.83 & 1553.324 & 246.551 & 6310 & 1556 & 1602 & 3112 & $2.9 \%$ \\
\hline 36 & $A L$ & 1542.881 & 1542.883 & 1565.628 & 1567.039 & 234.914 & 6310 & 1482 & 1496 & 2964 & $0.7 \%$ \\
\hline 38 & AK & 1520.532 & 1520.544 & 1567.016 & 1568.836 & 301.296 & 6310 & 1901 & 1966 & 3802 & $3.4 \%$ \\
\hline 40 & AJ & 1533.593 & 1533.601 & 1575.128 & 1577.488 & 392.002 & 6310 & 2474 & 2512 & 4948 & $1.5 \%$ \\
\hline 41 & $\mathrm{AH}$ & 1520.293 & 1520.293 & 1566.064 & 1568.512 & 408.027 & 6310 & 2575 & 2490 & 5150 & $3.3 \%$ \\
\hline
\end{tabular}

\section{CONCLUSION}

Aiming at the need of cable force monitoring of space cable structure, after analyzing the mechanism, advantages and disadvantages and application stages of existing cable force monitoring methods, this paper puts forward a joint monitoring method based on optical fiber clamp cable tension meter and Jack, and applies it to the second phase of National Conference Center, which realizes the effective monitoring of cable force construction process, The results are as follows:

1. The mechanism of joint monitoring method is clear and easy to implement; the advantages of clamp, tension meter, and Jack monitoring are brought into full play, and their disadvantages are avoided;

2. The effectiveness and superiority of the joint monitoring method are verified by the practical engineering application. In the mutual check stage of Jack and clamp tension meter, the error of monitoring data of the two testing methods is less than $5 \%$, which indicates that the clamp tension meter is accurate and effective;

3. The joint monitoring method makes full use of the tensioning equipment and Jack, as well as the construction technology of the project cable (tensioning in two times). The setting time of the clamp tension meter is selected after the first tensioning of the cable. This joint monitoring method has no effect on the original construction technology and construction period.

In summary, the data quantitative and qualitative analysis of the two types of sensors in the joint monitoring method show that the whole cable construction process of the steel roof of the project is safe and controllable, which provides the basis for the subsequent engineering construction. At this stage, the construction has just finished, and there is no data integration, so this paper only analyzes the construction stage, and the monitoring results of the service stage will be analyzed in the following articles.

Author's Contribuitions: Conceptualization, GUO Nan and LAN Chunguang; Methodology, GUO Nan; Investigation, WANG Xingang and LAN Chunguang; Writing - original draft, WANG Xingang; Writing - review \& editing, GUO Nan and 
LAN Chunguang; Funding acquisition, LAN Chunguang and GUO Nan; Resources, GUO Nan and WANG Xingang; Supervision, LAN Chunguang.

Editor: Marcílio Alves

\section{References}

Zhao Wenju, Zhang Guangwei, and Zhang Jian, (2020). Cable force estimation of a long-span cable-stayed bridge with microwave interferometric radar. Computer-Aided Civil and Infrastructure Engineering, 35.12.

Xin Cui, et al. (2013). The Research on Cable Force Measurement Based on Degenerated Element with Frequency Method. Applied Mechanics and Materials, 405-408.

Y. Zhao and M. L. Wang, (2008). Fast EM stress sensors for large steel cables. SPIE Smart Structures and Materials + Nondestructive Evaluation and Health Monitoring.

Smedt Elien, et al. (2021). Reliability-based analysis of a cable-net structure and membrane structure designed using partial factors. Architectural Engineering and Design Management, 17.3-4.

M. Rezaiee-Pajand and M. M. Khatami, (2021). Nonlinear analysis of cable structures using the dynamic relaxation method. Frontiers of Structural and Civil Engineering.

Lee Sung Hwa, et al. (2009). Implementation of A Bridge Monitoring System Based on Ubiquitous Sensor Networks. The Journal of The Institute of Internet Broadcasting and Communication.

Song Jong Keol, et al. (2008). Web-Based Bridge Monitoring System with Wireless Sensor Network Environment. Journal of Korean Society of Hazard Mitigation.

Deqing Guan et al. (2015). Damage identification method of suspension bridge structure based on wavelet - artificial immune algorithm. Proceedings of the 5th International Conference on Civil Engineering and Transportation.

Guo-Xi Fan, et al. (2020). Strain Conditions Monitoring on Corroded Prestressed Steel Strands in Beams Based on Fiber Bragg Grating Sensors. Sensors.

Lejiang Guo, et al. (2011). The Application of Bridge Monitoring System Based on Wireless Sensor Networks. Energy Procedia 11.

Xushe Zhang, Yanliang Du; Chenxiao Ning, (2005). A new monitoring method of cable tension of cable-stayed bridge-fiber Bragg grating method. Journal of Central South University of Technology (English Edition), 261-263.

R. Maaskant et al. (1997). Fiber-optic Bragg grating sensors for bridge monitoring. Cement and Concrete Composites, 19.1.

Ujiwara, T., Kajimoto, K. Yajima, M., Murai, R., Murakoshi, J. and Yamamoto, (1993). Development of bridge monitoring system.

Sung Tae Kim, et al. (2014). Long-Term Monitoring of FRP-Concrete Composite Bridge Deck for Cable-Stayed Bridges Using Optical Fiber Sensors. Key Engineering Materials, 577-578.601.

José R. Alves Cunha, et al. (2013). New approach to the strain analysis of bragg grating sensors. Photonic Sensors, 3.1.

Hong-yue Liu, et al. (2012). Design of a long-period fiber grating sensor for reinforcing bar corrosion in concrete. Journal of Intelligent Material Systems and Structures, 23.1.

Wei Wu, et al. (2009). The application of fiber grating sensor network in port machinery monitoring. Optics and Lasers in Engineering, 48.4. 